\title{
UN ESTUDIO DE LA HECHICERÍA AMOROSA EN LA LIMA VIRREINAL
}

\author{
A STUDY OF LOVE AND WITCHCRAFT \\ IN THE VICEROYALTY OF LIMA
}

JOSÉ MANUEL RODRÍGUEZ ${ }^{* *}$, NATALIA URRA $^{* * * *}$
MARÍA FERNANDA INSULZA****

\section{RESUMEN}

El interés por los juicios a las hechiceras durante la época colonial nos llevó a desarrollar una investigación acuciosa en los archivos de la inquisición madrileña sobre tales procesos en la Lima virreinal. En el desarrollo de nuestro trabajo nos encontramos con una serie de complejas relaciones sociales, políticas, culturales que los juicios a las hechiceras revelan. De ahí que nos planteásemos el objetivo de estudiar tales relaciones. Así llegamos a determinar, o conocer de cómo la hechicería limeña se configuró a partir de tres matrices culturales perfectamente diferenciadas: la europea, la africana y la indígena; del hecho que los hechizos más solicitados y recurrentes tuviesen un fin erótico-amoroso; del estatus que alcanzaron las hechiceras en la sociedad colonial del Perú, de la diversidad de las personas que recurrían al socorro de las prácticas mágicas. El trabajo que sigue detalla y ahonda en estas relaciones.

Palabras clave: Hechicería, juicios, inquisición, relaciones interétnicas, magia.

* Este artículo se escribió en el marco de una colaboración entre el proyecto Fondecyt 11110250 titulado "La presencia de las brujas en la narrativa latinoamericana contemporánea" y la investigación doctoral de la Dra. Urra, desarrollada en la Universidad Autónoma de Madrid. Agradecemos muy sinceramente el apoyo prestado por Fondecyt a nuestras investigaciones nocturnas.

** Doctor en Literatura Latinoamericana. Profesor de literatura latinoamericana de la Universidad de la Frontera. Temuco, Chile. E-mail: jose.rodriguez@ufrontera.cl

*** Doctora en Historia Moderna. Profesora de Historia de la Universidad Andrés Bello. Email: nataliaurrajaque@gmail.com

**** Profesora de Lengua Castellana y Comunicación. E-mail: m.fernanda.insulza@gmail. com 


\section{ABSTRACT}

The interest in witchcraft trials during the Colonial period led us to develop a diligent research in the files of the Madrilenian Inquisition about these processes in the viceroyalty of Lima. In the development of our work, we have found a series of complex social, political and cultural relationships that are revealed by the witchcraft trials and thus, we decided to study these relationships. We therefore determined, or came to know, that witchcraft in Lima was configured from three perfectly differentiated cultural matrixes: European, African and Indigenous and that the most requested and recurrent spells were those of an erotic-amorous nature. From the status reached by witches in the colonial society in Peru and the diversity of people who resorted to their help and magical practices, we can envision the construction of witchcraft as a resistance factor to the predominant order.

Key words: Witchcraft, trials, Inquisition, inter-ethnic relationships, magic.

Recibido: 14.02.14. Aceptado: 05.05.14.

Para las hechiceras coloniales

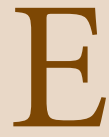

L GRAN NÚMERO de actividades mágicas desarrolladas por las acusadas de hechicería en la Lima virreinal durante el siglo XVIII, pareciera revelar la fragilidad de creencias de una sociedad colonial tan aparentemente cerrada a toda religión que no fuese la oficial, pero que se interesó por recurrir a los poderes del sortilegio para, fundamentalmente, curar sus males de amor. En general esta inclinación, según Caro Baroja (1967), se produce porque "pretender atraer a un amante desdeñoso o fatigado mediante conjuros, conminaciones, ligazones, etc., no es de hoy ni de ayer: es de siempre. Tampoco es propio sólo de una época el que la mujer misma, pasados ya los propios ardores, trabaje por cuenta ajena para procurar amores a otras mujeres u hombres" (95). De acuerdo al notable historiador español no fue accidente, entonces, el interés por buscar el celestino socorro de las brujas en el virreinato del Perú.

Ahora, no olvidemos que Caro Baroja considera esa vocación como una costumbre muy arcaica. De ahí que sea necesario dar una mirada al mundo de los muertos, al mundo antiguo, para indagar en las relaciones entre brujería y amor. Partimos por el Egipto imperial. Allí existía un gran desarrollo de las prácticas mágicas, la cuales resultan sorprendentemente similares a las ejecutadas por las hechiceras modernas. Un ejemplo lo podemos observar en un conjuro de una bruja rescatado por la historia: "De la misma forma que Thyphon es el adversario de Helios/ Paralelamente inflama el alma de Euthyches/ Que ha dado a luz Zóminas/ Dios Abrasax.../ 
En esta misma hora y hoy mismo/ Adonai/ Inflama el alma de Euthyches/ Así como su corazón, de amor/ (Sánchez Ortega, 2004: 178). Consignamos que claramente la brujería se usaba con fines amorosos en la civilización de los faraones. Ahora, si observamos al mundo grecolatino, heredero de las tradiciones egipcias, es posible observar que las hechiceras recurrían a ceremonias e instrumentos muy parecidos a los utilizados por la civilización del Nilo. Así en Grecia tuvieron mucho "éxito" Las trece tablas de plomo, escritos de origen egipcio hechos en madera, en las cuales se describían las actividades y conjuros realizados por las mujeres para obtener el cariño de un determinado hombre. En el ámbito romano podemos decir que el imperio albergaba un gran entramado de personajes de diferentes etnias dedicados a la magia. Las mujeres romanas acogieron las tradiciones procedentes de las múltiples expresiones culturales, complementando y enriqueciendo las propias. Y, al igual que las egipcias y las griegas, hacían uso de tablillas para dejar por escrito sus hechizos y conjuros. También utilizaban figuras de cera y elaboraban ungüentos y filtros amorosos e invocaban a las fuerzas oscuras. Incluso la gran literatura se hace eco de los conjuros de amor, como revelan estas líneas de Virgilio:

Nada aquí sino los ensalmos faltan/ Traed de la ciudad a casa, ensalmos míos, traed a Daphne/ Con ensalmos Circe transformó a los compañeros de Ulises/ La fría serpiente en los campos es destrozada por el canto/ Traed de la ciudad a casa, ensalmos míos, traed a Daphne (citado en: Sánchez Ortega, 2004: 187).

Las actividades mágicas se desarrollaron con libertad durante varios siglos en la Roma imperial. Ni siquiera la imposición del cristianismo como religión oficial acarreó una condena del paganismo y, por ende, de la brujería. La condena y la prohibición tardaron siglos en llegar. Además, la Iglesia ha sido muy astuta en ocultar sus relaciones con la hechicería y la magia, pues las actividades mágicas se mezclaron con esa nueva creencia hegemónica a niveles populares. La misma Iglesia, heredera de las tradiciones egipcias, fomentó a que ello se llevase a cabo. Es así que tanto Tertuliano como San Agustín aconsejaron implorar a Dios mediante oraciones milagrosas para provocar la lluvia o la cura de enfermedades. Como característica esencial tales oraciones no poseían límites definidos entre lo mágico y lo religioso. Algunos sacerdotes conjuraban con el objetivo de sanar las enfermedades y, en ciertos casos, provocar enlaces conyugales mediante ensalmos y evangelios. Importa destacar que desde los primeros tiempos del cristianismo es posible observar como los sacerdotes realizaban, y realizan, 
ceremonias y ritos que se componían tanto de elementos paganos como cristianos. Hablamos, por ejemplo, de la bendición del lecho nupcial con agua bendita y con la sal purificadora. Junto a ello estaba la purificación, para el caso del lecho nupcial por la cruz. Importa destacar que la misma misa y la consagración de la hostia están teñidos de paganismo. A pesar de que la iglesia católica condenaba fervientemente todo acto que atentara contra su omnipresencia, no modificó estas creencias pagano-cristianas ni siquiera después de la Reforma, por lo tanto prácticas directamente relacionadas con el paganismo como el culto a los santos, los exorcismos, las bendiciones y los sacramentos se mantuvieron. En suma, el cristianismo ayudó a perpetuar prácticas y ceremonias que podían ser percibidas por los fieles como mágicas y que, en la mayor parte de las ocasiones, eran varones eclesiásticos los protagonistas. La magia sacerdotal se "legitima" en el orden del discurso medieval. Éste reservaba el saber erudito, letrado, teológico, a los varones. En cambio, la cultura oral, popular, se abría al mundo femenino. Mundo donde se desarrolla la brujería. Quizás de ahí provenga el que las mujeres fueron consideradas especialmente dotadas para la práctica de la hechicería, pues se creía y, en algunos casos se afirmaba, que éstas poseían cualidades mucho más aptas para ejecutarlas. Por ende, sus artes -según los discursos hegemónicos- fueron vinculadas a una cultura popular, oral y netamente femenina y, sobre todo, transgresora y demoníaca.

La simbiosis entre las prácticas egipcias, grecorromanas y cristianas es posible de vincular con lo que se dice sobre los hechizos de las brujas limeñas en los archivos inquisitoriales de muchos siglos después. Las fuentes del Santo Oficio nos proporcionan "los datos necesarios para terminar de comprender el contenido y la forma de estos conocimientos y esta profesión transmitida oralmente gracias a las mujeres, y ejercida principalmente por ellas" (Sánchez, 1997: 193). En este caso, al igual que en el cristianismo, existe una continuidad histórica con la magia del mundo antiguo. De ahí que en las mencionadas prácticas ejecutadas por hechiceras ibéricas e hispanoamericanas durante los siglos modernos no existan diferencias notables con las desarrolladas por sus antepasadas egipcias o grecorromanas. Importa anotar un cambio relevante: las fuerzas oscuras o subterráneas ya no pertenecían a un panteón politeísta sino al eterno enemigo de Dios, es decir, al demonio.

Las acusadas de hechicería en la Lima virreinal, al igual que sus similares ibéricas, utilizaban los ritos y liturgias de la iglesia católica; suplantando a las deidades paganas provenientes del mundo precolombino que aparecían constantemente en sus invocaciones por una diversidad de santos proporcionada por el panteón cristiano. Su magia se caracterizó por ser una magia 
netamente casera, es decir, los instrumentos más habituales manipulados en sus conjuros pertenecían a la cocina de cualquier mujer. Los filtros ibéricos, por ejemplo, se sustentaban en los granos de trigo, las habas, la sal o el vinagre. En el caso virreinal los ungüentos se ejecutaban con hojas de coca o de tabaco. Lo más importante en estas actividades era la propia imaginación de las hechiceras, cuestión que, sin lugar a dudas, se comprueba en el amplio repertorio recogido por los inquisidores en los archivos del Santo Oficio. No obstante, lo que más destacaba era la confianza en "la fuerza de la palabra", pues allí radicaba el secreto del ritual y, principalmente, la fiabilidad de la mujer poderosa. Los métodos de la magia amorosa estaban compuestos por tres principios fundamentales:

a) Una invocación inicial, que puede ir dirigida tanto a la Santísima Trinidad, los tres santos de mayor devoción -san Pedro, san Pablo, y el apóstol Santiago- o una triada diabólica compuesta generalmente por Satanás, Barrabás y Belzebú.

b) Un cuerpo narrativo en el que se evoca la circunstancia que se quiere provocar -la llegada del galán, su fidelidad, su pasión adormecida o generosidad, etcétera- $y$ en el que se relata también algún hecho que pueda ayudar a la imaginación de la profesional o la mujer que efectúa el rito a entrar en situación.

c) Un estribillo final -que también aparece a veces entremezclado con el cuerpo principal de la invocación-y que actúa como resumen y culminación que se quiere provocar (Sánchez Ortega, 2004: 510).

En el virreinato del Perú, la variedad de las prácticas mágicas fue muy rica y significativa, fruto del gran entramado étnico que convergía en el territorio. La integración de ideas y creencias distintas (ibéricas, indígenas y africanas) a la hora de ejecutar un hechizo, provocó una gran variedad de prácticas híbridas, gracias a las cuales, como veremos, se pudo conservar parte importante de las tradiciones de la población autóctona y africana. Tradiciones que la Inquisición persiguió como transgresiones religiosas, siendo que muchas de ellas eran simples expresiones culturales. Otras son las prácticas mágicas que constituyen una

forma de aproximación al entorno, de puente entre individuos o sociedades y la naturaleza, cuya característica básica reside en que tienen eficacia simbólica... son un lenguaje, un sistema simbólico completo, con una lógica interna de funcionamiento, que se rige por sus propias reglas, su propia gramática y de acuerdo a sus propios mecanismos, y actúa donde otros saberes son ineficaces (Ceballos, 2001: 52). 
La misma investigadora plantea que, el acudir a las prácticas mágicas funcionó como escapatoria para los sometidos a la asfixiante moral de las sociedades coloniales, pues mediante ellas se regulaban importantes espacios sociales, el del encuentro amoroso y el de la rogativa y la esperanza. Pero, además de regular definían, en cierto sentido, el ethos de esos espacios, pues la mayoría de los y las encargadas de ejecutarlas eran "mestizos culturales" (Ceballos, 2001: 517). Así llamados porque en sus conjuros podían mezclar tradiciones africanas, indígenas y españolas. Dichos personajes fluctuaban en distintos ambientes, es decir, podían insertarse entre los diferentes grupos étnicos o entre las diversas culturas de una misma sociedad. La persecución hacia estos mestizos y mestizas y sus respectivas prácticas mágicas fue una de las formas de controlar la sociedad y, al mismo tiempo, de marginar a determinados grupos. Dado que las acusaciones recaían, principalmente, en indígenas, africanas esclavizadas, mestizas y mestizos y personas pobres. Por ende, prohibir sus ritos era utilizado por las autoridades hispánicas para homogeneizar la sociedad. Dicho objetivo no se cumplió. La autoridad no pudo impedir el cruce de tradiciones y prácticas. Una de las razones de la pervivencia fue la arraigada creencia en los poderes de los y las "mestizos(as) culturales". Así la mayoría de las personas recurrían a sus servicios creyéndoles seres especiales, capaces de solucionar sus conflictos personales. Era común, por ejemplo, buscar a los y las esclavos(as) africanos(as) que se relacionaban con blancos y frecuentaban espacios exclusivos de éstos, pues se pensaba que por tener ese privilegio de movilidad social, también poseían poderes y, por tanto, podían modificar las adversidades de la vida. Otra razón importante estriba en que algunos grupos sociales reconocieron las prácticas como algo no demonizado, sino distinto. Luego de un periodo en el cual se privilegiaron las acusaciones al ejercicio de ellas se dio paso, aproximadamente en el siglo XVIII, "a una visión más acorde con las diferencias etno-culturales propias de esa sociedad. Este proceso fue paralelo a un proceso de mestizaje cultural, que produjo también una transformación y mezcla de las diversas prácticas mágicas y de las tradiciones culturales en general, generando así fenómenos propiamente americanos" (Ceballos, 2001: 57). Las prácticas mágicas del Virreinato reunieron diversas tradiciones: por un lado, los blancos aportaron el uso e importancia de la palabra (ensalmos, conjuros, lectura de manos y cartas etc.), por otro, los negros e indígenas contribuyeron con los conocimientos sobre plantas y yerbas. Las prácticas mágicas ya no sólo fueron actividades de tipo hechiceriles, sino también actividades representativas de ese mestizaje social y cultural. La interacción entre las diversas culturas 
dio paso a una tradición singular que revela que las prácticas hechiceriles desarrolladas en la Lima virreinal, como ya habíamos adelantado, tuvieron semejanzas con las prácticas de las hechiceras ibéricas, de las indias y de las africanas. Así utilizaban filtros y ungüentos para fines eróticos, también maniobraban muñecos, animales, brebajes e imágenes indígenas del inca y la colla, incluso invocaban a los espíritus, a los santos, a la virgen María y al demonio (Mannarelli, 1998: 32-33). Respecto de este último, en el contexto virreinal se lo asociaba, mayoritariamente, a las deidades precolombinas. Idea que no fue inventada por la tradición mágico-popular peruana, sino, más bien, pertenecía a los principios fundamentales de la ideología judeocristiana, es decir, consistía en "una construcción ideológica de los grupos dominantes" (Mannarelli, 1998: 34). No sólo las mujeres de ascendencia indígena invocaban a las deidades precolombinas, sino también las españolas y las afrocoloniales, cuestión que nos reitera y refuerza la no existencia de barreras étnicas con respecto a la ejecución de las prácticas mágicas en el territorio colonial peruano. Al mismo tiempo, la presencia de este tipo de actividades

sugiere la existencia de una especie de cultura oral a la cual, lamentablemente, sólo se tiene acceso a través de los testimonios escritos por las élites. Las mujeres acusadas de hechicería participaron activamente reelaborando y enriqueciendo un código ritual, que se transmitía junto con los conocimientos empíricos medicinales colectiva o individualmente. La utilización de hechizos en forma verbal, la invocación al poder a través de la palabra, revelan también un intento de apropiación del lenguaje -con el objeto de expresar necesidades vitales y deseos- que de forma consciente o no las hechiceras ponían al servicio de otras mujeres de la sociedad colonial (Mannarelli, 1998: 34).

Con respecto a la invocación de fuerzas poderosas, debemos mencionar la existencia en el virreinato de un personaje diabólico de origen popular llamado diablo cojuelo. La gran mayoría lo nombra e invoca en sus conjuros, pues le atribuían enormes poderes y facultades en el plano amoroso. Los personajes demoníacos aparecían nombrados constantemente en los conjuros de nuestras protagonistas, aunque las prácticas hechiceriles no fuesen del todo maléficas. Sin embargo, en lo que a amores se refiere el apoyo del diablo era fundamental para alcanzar los objetivos deseados. Por lo tanto, su intervención era considerada imprescindible. Las sortílegas lo invocaban con la intención de cumplir los sueños y anhelos de sus clientas, cada una tenía una fórmula o estilo particular, pero el objetivo era siempre 
el mismo. La testigo número siete en el juicio contra Paula Molina expresó que queriendo casarse con un hombre que no la quería le pidió ayuda, entonces Paula ejecutando un hechizo con piedras imanes, alfileres y cabellos del supuesto hombre "la estubo refregando por la cabeza y por el cuerpo diciendo por tres veces: para que se case, y que diciendo la declarante Jesus, la dijo: no se nombra, antes se llama al Diablo" (AHN 5346, No 2, folio 42rv.). Por su parte, la testigo número diez, de nombre María Antonia Salina, relató que para tener fortuna, Paula Molina le dijo que

hiciese pacto con el demonio llamandolo y diciendole: no me desampares que yo te serviré y sere tuya, lo que executo varias vezes diciendo: Lucifer asi como protejes a Paula, me haz de proteger, haz que tal hombre me quiera y que no trate con otra: que tambien dijo que para que consiguiese este fin pitase zigarros y dijese entonces: Lucifer haz que este hombre este rendido para con migo, lo que practico varias vezes" (AHN, legajo 1649, Exp. № 13, imagen 17).

La relevancia de la vinculación que hicieron algunas mujeres entre el demonio, las divinidades precolombinas y las prácticas hechiceriles, consiste en que a través de ella logran hacer trampas a la cultura impuesta y mantener vivas, aunque fuera de manera oculta, costumbres y tradiciones particulares o propias de los grupos dominados o sometidos. Esta misma situación generó la utilización de una variedad notable de objetos en sus conjuros, entre ellos cruces consagradas a los idolillos o figuras sagradas procedentes de las huacas (lugares utilizados para celebrar ceremonias religiosas precolombinas). La presencia de tales figuras en los diferentes conjuros o hechizos simbolizaba, entre otras cosas, la unión y las relaciones interétnicas que cohabitaban en los distintos estamentos de la sociedad colonial y, por otra parte, la sobrevivencia de antiguos ritos indígenas. Además, la presencia de elementos propios de los ritos andinos en la hechicería virreinal provocó que las mujeres que realizasen dichas prácticas quedaran en una posición superior, inapropiada para su sexo, según el diseño patriarcal, pues no sólo eran peligrosas por transgredir las normas, sino también por vincularse y aliarse a los enemigos de la cristiandad, en este caso a la tradición pagana y a la tradición andina. De ahí que se las catalogase como peligrosas y enemigas del orden establecido. Razón por la cual intentaron disimular sus conocimientos y saberes. Y quizás esta sea otra forma de explicar el sincretismo entre hechicería precolombina y cristianismo, pues al usar elementos propios de la religión dominante, las prácticas se teñían de un aura oficial. 
Tampoco hay que olvidar que las prácticas mágicas femeninas desarrolladas en la Lima virreinal durante los siglos XVI al XVIII constituyen, en cierto sentido, una forma distinta de representar los ritos cristianos. Las mismas fuentes inquisitoriales nos lo corroboran al describir rituales y objetos propios de las liturgias cristianas en los hechizos realizados por gran parte de las mujeres acusadas de ejecutar tales actividades. Los hechizos y prácticas mágicas ilustraban la separación del universo material y espiritual, cuyos atributos positivos y negativos se dejaban percibir constantemente en las diferentes invocaciones realizadas, pues era común que apelaran tanto a la buena voluntad de las jerarquías celestiales como a la de las infernales. La influencia del cristianismo en los conjuros predominó de tal manera que Dios y sus santos eran nombrados con la misma frecuencia que el demonio y sus secuaces. Así invocaban a la Santísima Trinidad y a la Virgen María, sin olvidar, por supuesto, a Jesucristo. Juana Saravia, por ejemplo, invocaba a San Pedro y a San Pablo, mientras que María de Valenzuela a San Santiago, pues decía que éste era el abogado de las hechiceras y Juana de Santamaría, por su parte, repetía: "Dios yaya, otra en el pecho, dios churi y otra de ombro a ombro, Dios espíritu Santo" (AHN Inquisición, legajo 5346, № 2, folios 110-116). En suma, como ya adelantamos, el cristianismo aportó una amplia compilación de santos y santas fundamentales para la obtención de los amores deseados. Destacan los provenientes de la Leyenda Dorada, un santoral fabricado en el siglo XIII y divulgado hasta finales del XVII. En esa lista figuraban Santa Marta y Santa Elena, ambas santas fueron esenciales en los conjuros de las hechiceras hispánicas y virreinales. Santa Marta, por ejemplo, era invocada como la hermana de Lázaro o como "Marta la mala" y Santa Elena como una mujer milagrosa cuyos poderes revivirían la pasión del amante alejado. A ella se le atribuyó el hallazgo de las cruces en las que fueron martirizados los ladrones que acompañaron a Jesús y, por si fuera poco, se le consideraba la madre del emperador Constantino y emperatriz de Bizancio. Por otra parte, éstas eran las únicas mujeres que aparecían en este famoso santoral, los otros eran todos varones: San Antonio, San Silvestre, San Marcial, entre los más reconocidos.

La hechicera Juana de Santamaría recurría a las virtudes de esos santos y santas utilizando conjuros como el siguiente:

Santa Elena de Reina y Rey que saliste en busca de jesuchristo, y encontraste con onse mil vírgenes, y les preguntastes que buscaba, respondio que los tres clabos denño señor jesuchristo, y te revelo el angel, que hay estaban los tres clavos debajo de la tierra, y guando recordates y cabate 
la tierra abisastes alas once mil virgenes habías hallado los tres clavos, y de ellos echaste al mar un clavo paraque quedase salado otro a su hijo Constantino, y el otro que con la crus, para que le diera señas a los christianos" (AHN Inquisición, legajo 5346, № 2, folios 59rv.-60v9).

Los rituales cristiano-católicos inspiraron a las hechiceras ibéricas y virreinales y sirvieron de insumos para las artes de estas mujeres. Los sacerdotes, por un lado, recomendaban ciertos rezos u oraciones para sanar enfermedades físicas, mientras que las hechiceras lo hacían para reconquistar los amores perdidos. Trabajo que no se reducía sólo al uso de plegarias, sino además al de objetos como el ara o las velas sagradas, los cuales servían para unir a dos personas o provocar esterilidad o impotencia en los amantes. Gabriela Herrera, testigo número once en el juicio contra Juana Prudencia Echeverría, declaró que después de ser abandonada por su respectiva pareja y con el objetivo de que éste volviera, "la mamá Juana le dio un baño diciendo al mismo tiempo: maldita maldita sea o Dios consumida: Las raizes te cortare a los montes de Granada donde perro ladre ni gallo cante y que la dijo que aquella era una oración suya" (AHN Inquisición, legajo 1649, Exp. No 25, imagen 16). Las sortílegas también incluían la invocación a los espíritus, tradición que provenía del mundo antiguo, pues tanto las hechiceras egipcias como las grecorromanas creían en las facultades maléficas de los muertos. Fue así como el universo mágico-ibérico y colonial incorporó las ideas del infierno y la condena del alma, sirviendo esto como base para la creencia "que por temor a vivir lo mismo que estas personas, los amores deseados y perdidos volverían a ellas"(Sánchez Ortega, 2004: 381-390). Francisca de Mondragón, por ejemplo, pedía a sus clientas sangre de carnero para ejecutar con efectividad sus hechizos. Hechizos que realizaba los miércoles y los viernes, pues sostenía que en tales días el demonio prestaba mayor ayuda. Los inquisidores, por su parte, sostuvieron que Juana de Santamaría utilizaba en sus hechizos huesos de muertos, entre ellos una calavera a la que le encendía unas velas para que ésta la socorriese en sus peticiones. Y María Rosalía recomendaba a una de sus clientas rezar "tres credos al salir de su casa, y refugarce una cadena de ajos en el suelo llamando a las almas de los condenados"(AHN Inquisición, legajo 5346, № 2, folio 38 rv).

Interesa, en este instante, ahondar en la influencia del mundo andino en las prácticas mágicas dadas en el Virreinato del Perú. Era común utilizar yerbas, plantas e idolillos típicos de los rituales precolombinos. Lo más habitual era la utilización de la coca, cuyas hojas, dicen los inquisidores, son como de laurel de que siempre han abusado los indios mascándola para no sentir trabajo. Los procesados aseguraban que la usaban para limpiarse los 
dientes y curar sus enfermedades, pero lo cierto era que con el tiempo no podían prescindir de ella, porque los que comienzan una vez a mascarla "los ceba el demonio de manera que no la pueden dejar" (Castañeda y Hernández, 1995: 20). La coca fue un instrumento clave en los ritos y ceremonias precolombinas, los conquistadores la vincularon a las supersticiones, concibiéndola como una yerba maléfica y "universal en todas las huacas" (Castañeda y Hernández, 1995: 22). De ahí que la planta pasase a ser un verdadero obstáculo para la imposición de la cultura y religión dominante. En reiteradas ocasiones los mismos inquisidores pidieron la erradicación de la arraigada costumbre de chacar ${ }^{1}$ entre los indígenas, solicitando que se les otorgara potestad jurídica sobre los naturales para lograr su objetivo. Sin embargo, eliminar la costumbre era difícil, puesto que los poderes curativos y medicinales que poseía la coca les permitían soportar los rigores climatológicos del altiplano y, por tanto, sobrellevar trabajos pesados sin sentir hambre ni sed. Muchos de los que la usaban en este sentido, incluso, decían "no tener conciencia de las causas reales que provocaban su alucinación, achacaban las sensaciones que sentían a una causación mágica" (Sánchez, 1997: 149). Quizás, por esta misma razón en cédulas reales, como una de Felipe II en 1569, se negaban a prohibirla por completo, aunque sí solicitaban un uso adecuado para evitar adicciones o dar paso a posibles transgresiones idolátricas. En los ámbitos urbanos el consumo de la coca estaba estrechamente vinculado a las prácticas mágico-hechiceriles, ya que como yerba alucinógena provocaba estados de embriaguez durante los cuales, según las hechiceras, se conectaban con el inframundo. Respecto del uso de la coca en los conjuros podemos citar, por ejemplo, a María de Valenzuela quien hacía sahumerios con las hojas de la planta; Rosa Ramona, por su parte, la mezclaba con aguardiente; Luisa Contreras mascaba sus hojas y luego las escupía para hacer sus maleficios(A.H.N. Inquisición, legajo 5346, № 1, folios 76-80562; legajo 5346, № 1, folios 91-102; legajo 5346, No 2, folios 27-34).

La complejidad y "las contradicciones" de la hechicería virreinal queda de manifiesto en relación al uso de la coca, pues en algunos conjuros en que participaba la planta las mujeres pedían a sus clientas y clientes despojarse de todo tipo de objetos cristianos o piadosos como los crucifijos, para así lograr con eficacia lo solicitado. María Rosalía, junto a sus ayudantes, exigía a sus clientas arrancarse el rosario, pues decía que sólo así el diablo le ayuda-

${ }^{1}$ Término utilizado para explicar la costumbre indígena de masticar hojas de coca durante horas hasta formar una bola en la boca. 
ba a solucionar los pesares. Ella además ejecutaba sus conjuros los viernes, pues creía que por ser el día que murió Jesús, el demonio la socorría con mayor disposición. En la Audiencia de Acusación contra Lorenza Vilchez, celebrada en Lima el año 1773, los inquisidores expresaron que mantenía relaciones sexuales con el demonio, quien le ordenaba quitarse "el rosario y la cruz y obedeciéndole se lo quitó del cuello... Que el demonio la decia no amase a Dios, no rezase no oyese missa, no hiciese oficio alguno de christiana" (A.H.N. Inquisición, legajo 1656, Exp. No 4, imagen 12). Otras, y aquí se marca el carácter complejo del asunto, recitaban palabras de admiración e incluso mimaban las hojas de coca, y con el propósito de crear un ambiente adecuado conjuraban e invocaban en nombre del inga y la palla y también en nombre de Santa Marta o San Santiago. Juana de Santamaría, por ejemplo, le pedía "ablanda el corazón de este hombre... (nombre del galán)..., havísame sí quiere a esta mujer... linda coca mama coca, quinto coca de ti me valgo, ablanda el corazón de aquel hombre"(A.H.N. Inquisición, legajo 5346 , No 2, folio 55v). En resumen, por un lado, la coca llevaba a conjurar contra y, por otro, en el nombre de Dios.

Destacamos en relación a lo anterior que de las treinta y ocho mujeres procesadas por el tribunal limeño en el siglo XVIII, ninguna dudaba de los beneficios de la coca, pues en cada uno de los testimonios descritos por los inquisidores se relata la utilización de esta hierba y, sobre todo, se destaca la creencia curativa y milagrosa que las hechiceras le otorgaban. La gran mayoría terminaba sus rituales en estado de trance, por lo tanto, fomentaron "la creencia de que mascando las hojas de coca [...] desarrollaban facultades para adivinar cosas secretas" (Sánchez, 1997: 150). Las clientas de Sebastiana de Jesús, por ejemplo, confesaron al Santo Oficio que, en cierta ocasión, el diablo le habló a la acusada en forma de gallo y otra vez en forma de gallina y que, además, una voz femenina le advirtió de un terremoto. Frente al anuncio, Sebastiana pidió a los santos que por favor evitaran tal desgracia. Luego, al no ocurrir el sismo, se decía a sí misma "Santa soy Santa soy” (A.H.N. Inquisición, legajo 5346, № 2, folios 167-172).

Elementos comunes en los hechizos limeños son también los cuyes, conchuelas, maíz, ají, tabaco y chicha. Todos objetos esenciales en las ceremonias religiosas precolombinas $y$, por supuesto, no faltaban las invocaciones a las deidades incas, entre ellas, la coya, los cerros, la luna o el sol, etc. Juana Novoa, muchas veces, complementó los poderes curativos de la coca con piedras imanes, hojas de tabaco, mote, cuyes asados e invocaciones a San Pedro y a San Pablo, pero además invocaba al sol llamándolo padre y señor; María de Silva conjuraba en nombre de las huacas y pallop, mientras 
que Dominga de Rosas utilizaba, además de coca y aguardiente, tierra de huacas. Juana de Santamaría, enterraba un membrillo en la puerta de su cuarto para que no le hiciesen daño otras mujeres y guardaba una araña en una canasta para tener fortuna, además, en sus sahumerios mezclaba las hojas de coca con granos de trigo negro y blanco, mostaza y aguardiente.

Un fenómeno de suyo interesante es que el mestizaje en la hechicería ocurrió también con las hechiceras ibéricas. Ellas comenzaron a utilizar los baños o sahumerios típicos del universo andino para sanar enfermedades. Rosa Gallardo, quien figura en el expediente inquisitorial limeño como española, declara que sus conocimientos provenían de un tal Felix Ayanque y una mulata llamada Chana Caldera, quienes le enseñaron a interpretar la suerte de sus clientas mascando hojas de coca. Otras de las asimilaciones propias del universo indígena y utilizadas, más tarde, por las hechiceras ibéricas fue la vinculación entre el demonio y el apóstol Santiago, pues en algunos testimonios inquisitoriales se describe la oración al diablo cojuelo utilizando imágenes de este santo. Los relatos también describen el uso de unos amuletos confeccionados con plumas de pájaros, muy típicos de las tradiciones incas. La asimilación de creencias tanto de un grupo como de otro se debe a que cada uno creía en las facultades especiales de los otros. Los blancos, por ejemplo, atribuyeron habilidades mágicas y poderes únicos a los indígenas y a los negros, cuestión plasmada en los relatos inquisitoriales, pues muchas de las mujeres describen cómo los hechiceros indígenas les enseñaban sus artes o conocimientos. Nicolasa de Cuadros, por ejemplo, era mestiza y decía haber aprendido de una india sus conocimientos hechiceriles; Juana Novoa también expresó haber aprendido las artes hechiceriles de un cierto indio y Juana de Santamaría confesó haber sido instruida por un indio, quien además le daba baños de hierbas machamacha y maiguanco.

Una tercera influencia, o una tercera matriz de la hechicería del virreinato, llegó con la diáspora africana hacia América. Empresa siniestra, como tantas otras emprendidas por Occidente, ese dudoso colectivo imperial.

Con la llegada de los esclavos llegaron también sus "prácticas, creencias, símbolos e imaginarios propios de su origen y de sus interrelaciones histórico-culturales" (Díaz, 2005: 223). El mismo autor sostiene que más allá "de negar o afirmar la supervivencia de la cultura africana, el tema real es establecer la naturaleza de la interacción y el cambio cultural de herencias que adquirieron sentido y realidad en los escenarios coloniales americanos" (223). La primera interacción ocurrió en el Atlántico, pues no olvidemos que durante el traslado de un continente a otro los sometidos a la cruel- 
dad infinita de la esclavitud intercambiaron tradiciones muy distintas. En este caso el traumatismo de la desterritorialización, el horror y la fatalidad de los esclavizados impulsó un proceso de reintegración étnica... quizás el único modo de unirse frente a la desesperación. Así en el trayecto no sólo se alteraron las identidades comunitarias sino que además se reinventaron étnicamente.

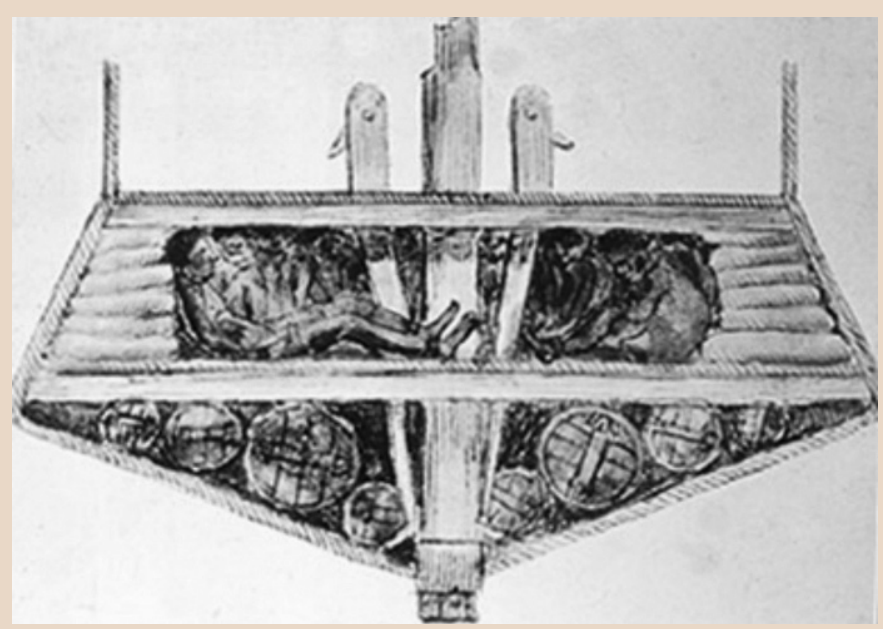

Posición de los negros en el barco (fuente: portal Unesco.org).

Sin entrar al muy tratado mestizaje, debemos consignar en relación a nuestros desarrollos que la confrontación cultural que se dio en la América colonial no necesariamente produjo una cultura mestiza, sino muy especialmente una "cultura popular". Concepto que indica un escenario donde confluyen elementos europeos, precolombinos y africanos que se combinan por "negociación, imposición y resistencia" (Ramos, 1994: 223-226). En específica relación con la hechicería como producto de esa mezcla cultural, podemos anotar que ella ofreció a muchas mujeres esclavizadas un espacio de libertad y autonomía. Sus conjuros, pociones y ungüentos fueron tan requeridos por la sociedad que llegaron a ser admiradas y temidas a la vez. La mayoría de las hechiceras, mujeres negras y esclavas, lograron fama y prestigio. Lo que les significó adquirir un estatus dentro de su propia etnia y también entre los otros grupos sociales. Por otra parte, estas prácticas -como ya hemos dicho- atentaban contra el orden moral y jerárquico de 
la sociedad colonial, principalmente "contra los preceptos de la moralidad conyugal católica" (Maya, 2002: 109), pues ensalzaban el goce y la sensualidad en desmedro de una sexualidad monogámica y reproductiva. En este sentido, analizar las prácticas mágicas nos permite conocer un devenir en el modo que las africanas esclavizadas percibieron qué significaba para el cuerpo la esclavitud y luego la resistencia por medio de la hechicería. En relación a lo primero, ellas percibieron que tenían un nuevo cuerpo y una nueva alma sometida al mandato del amo. Importa considerar el problema que plantea esta percepción, pues pareciera conjugarse con la idea del alma que propone la filosofía postestructural. Para ella el alma es una construcción del poder, como dice Foucault es el efecto de una "anatomía política" (2000: 32). En términos más generales, recordamos la reflexión de Deleuze sobre el CsO (cuerpo sin órganos): "El cuerpo sin órganos se opone, pues, no tanto a los órganos como a la organización de los órganos, en la medida en que ésta compondría un organismo" (2000: 37). El organizador de los órganos no sería otra cosa que el alma, invención de la teología, que permite organizar un cuerpo que es puro devenir. En relación con las esclavas, podríamos decir que ellas tenían un alma africana, el alma de su etnia. Allí se cobijaban sus dioses, sus vínculos de parentesco, sus ritos. Alma de la cual fueron despojadas violentamente y que fue sustituida por el alma que la colonia, como toda época lo hace, instala en los sujetos. Hablamos de un alma donde anidaban el rey, el Buen Dios, la esclavitud, la obligación de obedecer.

Frente a lo anterior, sus conocimientos y la práctica de la magia ayudaron a las sortílegas a "construir una autonomía cuyo territorio era su propio cuerpo" (Maya, 2002: 110). La misma autora luego sugiere que tal autonomía

parece haberse constituido sobre una inteligencia de los sentidos y de la corporalidad. Esta hipótesis adquiere mayor relevancia si se tiene en cuenta, según la legislación colonial, que el esclavo era un objeto, una mercancía o un bien mueble. Partiendo de esta consideración jurídica, la magia amorosa era una forma de resistencia al cautiverio, pues convertía al cuerpo y a las pasiones en fortín y estándares de la reconstrucción de la sexualidad y, por ende, del ser persona, aun viviendo en calidad de esclavas (111).

Llevadas estas líneas a los términos usados arriba, podemos decir que practicar la magia permitió a las negras sacudirse de las férreas cadenas del alma colonial y recuperar su cuerpo sometido. 
Las normas coloniales intentaron, evidentemente, conjurar dicha insurrección a través de la sanción física y la represión moral. En este punto se puede observar una diferencia entre los castigos a mujeres y hombres: las primeras eran sometidas a vejámenes o torturas emocionales y corporales. Eran sentenciadas, principalmente, a doscientos azotes y a "la vergüenza pública”, consistente en ser paseadas por las calles más concurridas de la ciudad desnuda de la cintura hacia arriba a cuestas de un burro y con insignia de sortílegas. Situación muy desigual cuando se trataba de los hombres, ya que a éstos se les evitaba dicho escarnio. De ahí que creamos de suyo interesante profundizar a futuro en un estudio que analice, reflexione y explique tales diferencias en las sentencias dadas a unas y otros, pues allí se evidencia una problemática de género que no deja de impresionar.

De regreso al asunto, sabemos que en la configuración de la hechicería virreinal las mujeres africanas y afrocoloniales reprodujeron prácticas mágicas yorubas ${ }^{2}$, las cuales mezcladas con los saberes y elementos propios de la América precolombina y la Europa cristiana también simbolizaron una rebelión para los inquisidores, pues incitaban a la lascivia, la concupiscencia y la promiscuidad. De ahí que persiguieran y castigaron las actividades hechiceriles latinoamericanas mucho más que en la metrópoli.

Yendo a un estudio de casos relacionados con estas últimas apreciaciones veamos primero a Paula Molina, mujer perteneciente a la casta afrocolonial. Ella ejecutaba hechizos para ayudar a otras mujeres abandonadas por sus respectivas parejas. Se trata de personas que no estaban casadas legalmente, sino que convivían de forma ilícita. De ahí que el temor de ser abandonadas poblase su cuerpo y su corazón, por ende solicitaban a la hechicera su intervención cada vez que su amante se ausentaba por un tiempo prolongado. La ya citada testigo María Antonia recurrió, en cierta ocasión, a Paula Molina para decirle

que el hombre con quien trataba sele havia hido, y deseaba selo hiciese volver a que le respondió, estaba ya separa de eso pero que tenia quien hiciese por ella, lo que no obstante la pidió dicha Paula una prenda del referido suxeto, como lo hizo dándole un alfiler del referido hombre, el que llebo asu casa y en la que se junta Micaela Guinda (ya difunta) que tenia la misma fama de bruja y a pocas oras le debolvio el alfiler doblado

\footnotetext{
${ }^{2}$ Hoy en día no existen documentos que nos aclaren con exactitud el origen geográfico de los esclavos africanos, sin embargo, estudios colombianos y cubanos e incluso brasileños estiman que hacia las costas caribeñas de Cartagena de Indias (principal puerto esclavista de Hispanoamérica) arribaron poblaciones Ewé, Aja y Fon, etnias originarias del Golfo de Guinea y actuales repúblicas de Togo y Benín.
} 
sobre una piedrecita y atado con seda carmesí, diciendiola: toma que ya tienes seguro ese hombre a hora te buscara lo que no tubo efecto (A.H.N. Inquisición, legajo 1649, Exp. № 13, imagen 15).

Luego, más directamente relacionado con la sexualidad, las mujeres afrocoloniales en sus hechizos utilizaban cabellos, uñas o pelos púbicos, pues creían que con tales materiales representaban a la persona en su totalidad y sólo así podían lograr sus objetivos. María del Rosario Perales, por ejemplo, era una mulata libre cuyos hechizos contenían, además de los citados, tabaco y aguardiente, pelotitas de algodón en representación del hombre y sus clientas. María de Monserrate y Santisteban era una mulata que fabricaba hechizos con sangre menstrual. Pedía a sus clientas que le llevaran una prenda interior con dicho elemento, además utilizaba un muñeco de cera en representación del hombre (AHN Inquisición, legajo 5346, No 1 , folios 134-143). La magia amorosa femenina generalmente procuraba despertar una pasión descontrolada en los amantes, donde el fuego y las llamas eran el elemento esencial para lograrlo; en este caso, se arrojaban "determinados objetos al fuego para que ardieran y se abrasaran como las ejecutantes esperaban que lo hiciera el corazón del hombre a quien iban dirigidos"(Tausiet, 2004: 521). Al mismo tiempo, estas llamas abrazadoras despertaban a los habitantes del inframundo, por lo tanto,

hacían alusión al tan extendido motivo folclórico del viaje nocturno se identificaba con el sabbat y que, en el mundo de la hechicería amorosa hallaba su expresión fundamental en la proyección demoníaca de los deseos de la conjuradora (Tausiet, 2004: 525).

Los deseos y anhelos se transportaban a cuestas de estos espíritus, los cuales, imaginariamente, capturaban a la víctima. Por consiguiente, debían ser tan veloces como la expansión del fuego, de ahí la unión hechiceril entre llamas abrazadoras y espíritus demoníacos. María Rosalía era una asidua a comunicarse con los demonios, pues con esto aseguraba la efectividad de sus hechizos. En reiteradas ocasiones los testigos describen que encendía velas y que las llamas simbolizaban la comunicación con ellos. Otros hechizos se respaldaban "en la ley de contacto o contagio, según la cual las cosas que alguna vez estuvieron juntas quedan después, aun cuando se las separe, en tal relación simpática que todo lo que se haga a una de ellas producirá parecidos efectos en la otra" (Tausiet, 2004: 527). Es decir, si determinadas partes del cuerpo, tanto de la mujer como del hombre, se rozaban o tocaban, quedaban vinculados eternamente. Sin embargo, conseguirlo no 
era fácil, para ello lo más habitual era la utilización de cabellos, uñas o sangre menstrual de la propia solicitante, quien -por orden de la hechicera- los mezclaba con las comidas o bebidas del respectivo amante. Rafaela Rodríguez, por ejemplo, solicitaba a sus clientas orines de hombres y restos de semen, los cuales los mezclaba y entregaba como verdaderos brebajes; Rosa Gallardo y Rosa Ramona, eran otras que pedían restos de semen para ejecutar sus conjuros, pues aseguraban que dicho elemento era fundamental para atraer a los hombres dóciles y enamorados; Fabiana Sánchez pedía cabellos y uñas, y Juana de Santamaría ordenaba a sus clientas lavarse las partes íntimas con chicha o aguardiente para luego dárselo a beber al hombre deseado (AHN Inquisición, legajo 5346, No 1, folios 91-102; folios 27-34; folios 185-191; folios 27-34; folios 185-191). Otros conjuros consistían en fusionar el semen o los cabellos masculinos con partes del cuerpo femenino. De la misma manera que los materiales antes mencionados, la ropa se transformó en un objeto altamente utilizado para estos fines por su contacto con el cuerpo de los individuos, pues como nos sugiere Francisco Fajardo (citado en Tausiet, 2004), "los vestidos eran -con sufrimiento para la higiene- una segunda piel, ya que, al ser escasos, se usaban durante mucho tiempo y caracterizaban por completo a aquel que los llevaba" (529). Basándose en estas razones, María de Valenzuela, Manuela de Castro y Fabiana Sánchez solicitaban prendas usadas por los respectivos galanes a conquistar. La primera, por ejemplo, pedía los calzones, la segunda las medias y la tercera los trapos viejos (AHN Inquisición, legajo 5346, № 2, folios 110116: folios 101-109; folios 192-202). Cada una tenía su estilo propio para maniobrar tales prendas, sin embargo, todas las utilizaban para representar al varón que se quería conquistar.

Recordamos, ahora, que al inicio del estudio escribimos sobre las condiciones que se fueron generando para que hubiese una relación entre la mujer y los hechizos. De acuerdo a nuestras investigaciones, comprobamos que las prácticas mágicas desarrolladas en el virreinato del Perú no sólo fueron ejecutadas sino también requeridas por mujeres, pues la gran mayoría de testigos y denunciantes eran de sexo femenino. La mayoría, o todas, de las denunciantes y testigos no vivían bajo la protección familiar de un padre, hermano o marido. Eran solteras, amancebadas o abandonadas por sus respectivas parejas. Un autor de la época, Martín de Castañega (citado en Millar, 1998), señalaba que las mujeres solicitaban las intervenciones mágicas mucho más que los hombres, principalmente porque:

Christo las apartó de la administración de sus sacramentos, e por esto el demonio les da esta autoridad, más a ellas que a ellos en la adminis- 
tración de sus execramentos. Lo segundo porque más ligeramente son engañadas del demonio, como parece por la primera que fue engañada, a quien el demonio primero tuvo recurso que al varón. Lo tercero, porque son más curiosas en saber y escudriñar las cosas ocultas e desean ser singulares en el saber, como su naturaleza se lo niegue. Lo quarto, porque son más parleras que los hombres, e no guardan tanto secreto, e así se enseñan unas a otras, lo que no hacen tanto los hombres. Lo quinto, porque son más subjetas a la yra, e más vengativas, e como tiene menos fuercas para se vengar de algunas personas contra quien tiene enojo, procuran e piden venganza e favor del demonio (257).

Así pues, los discursos hegemónicos incentivaban el miedo y, en algunos casos, el odio hacia las mujeres, sobre todo porque de acuerdo a los planteamientos religiosos, jurídicos e incluso médicos, éstas eran menos racionales que los hombres, por tanto más fáciles de seducir por el demonio.

La verdad es más simple como hemos visto hasta aquí, pues la mayoría de las mujeres comprometidas en el asunto buscaban en la hechicería soluciones a sus pesares sentimentales. Sólo en contadas ocasiones los inquisidores describen conjuros con otros fines. La razón de ello, según algunos representantes de la moral en la época como Jorge Juan y Antonio de Ulloa se cifra en la excesiva libertad moral y sexual practicada en una sociedad en la que el diseño importado de Castilla se desdibujó desde los primeros momentos de la colonización y si bien nunca desapareció el orden sepulcral que traían los íberos, las situaciones de excepción vividas en los primeros tiempos de la conquista contribuyeron a su relajación. A tal punto que algunos observadores de las costumbres de la Lima virreinal nos hablan de una nueva Sodoma y Gomorra. No obstante, reducir el uso de la hechicería a la búsqueda del placer sexual es insuficiente, ya que a pesar de ser un factor determinante el acudir a las sortílegas, la necesidad sexual por parte de las mujeres adultas que no encontraban pareja, también influyó en la existencia de un gran comercio mágico. Principalmente porque las mujeres que recurrían a los conjuros no sólo buscaban afecto concreto masculino, sino también las animaba el deseo de llevar una vida sentimental acorde a los cánones de la época. Es decir, tener una unión legítima que les brindaría cierto estatus, protección y solvencia económica. En otras palabras, anhelaban llevar una "vida en pareja" (Millar, 1998: 258-259). Vicenta Corbalán, por ejemplo, testigo número diez en el juicio contra Juana Prudencia Echeverría, de casta zamba y soltera, expresó que en varias ocasiones la mama Juana le dijo: "Daría fortuna y le traheria aun hombre que la daría mucha plata y en otra que la traheria un negro gran brujo y fino, el qual les haría 
toda fortuna" (AHN Inquisición, legajo 1649, Exp. No 25, imagen 14). La búsqueda de pareja masculina no es un asunto simple. No hay que olvidar que en las sociedades coloniales campeaban las ideas patriarcales y misóginas sobre el sexo femenino al que adjudicaban un estatus de inferioridad y sometimiento frente a los hombres y de allí la necesidad de protección y legitimación por medio del matrimonio. Sin embargo a veces las mujeres no buscaban protección, por el contrario, el casarse les daba una amplia libertad para salir en busca del placer.

Con respecto a la búsqueda del amor, los investigadores Luis Millones y Laura León (2003) sostienen:

conseguir o retener a la pareja es una de las preocupaciones más antiguas y angustiosas del género humano... la ansiedad por el éxito no reconoce moral ni permite descanso..., en algún momento, al palidecer las esperanzas, se hace indispensable el apoyo sobrenatural (149).

En suma, las prácticas mágico-hechiceriles femeninas buscaban romper con la realidad erótico-sentimental de poder existente, en el cual la mujer era subyugada por el hombre. Esto se hace evidente a través de estas prácticas en las que

ya se trata de atraer a un potencial amante indiferente, de captar la atención de un hombre en buena posición económica o de recuperar a un marido infiel paralizando sus ardores por una tercera persona, el objetivo perseguido en todos los casos consistía en subyugar totalmente la voluntad y la libertad del otro (Tausiet: 514).

Por otra parte, las hechiceras también podían desunir o desligar a una determinada pareja e incluso deshacer los hechizos realizados por terceras sortílegas y hasta los ejecutados por ellas mismas. Para conseguirlo maniobraban con objetos filosos como espadas, tijeras o clavos. Todos elementos que representaban la liberación. Una acción mágica común utilizada para separar a un hombre de una mujer era el enterrar ciertos objetos, pues con dicha acción se pretendía simbolizar la muerte o parálisis absoluta de aquella relación sentimental. Dominga de Rosas, por ejemplo, era una hechicera experta en quitar maleficios, pues siempre recurrían a ellas mujeres supuestamente maleficiadas por otras sortílegas; María de Monserrat y Santisteban y María del Rosario Perales no sólo los evitaban sino que también los ejecutaban, mientras que Juana Novoa, Manuela de Castro y María de Valenzuela los impedían; además, ésta última ordenaba a sus clientas enterrar 
determinados objetos en las cenizas del brasero, como las mezclas de coca, mistura y clavos de canela, pues según ella los hombres vendrían dóciles y locos de amor; similar pensamiento tenía María Rosalía, pues también creía que a través de los entierros de pájaros vivos aderezados con mejunjes los hombres volverían con sus clientas (AHN Inquisición, legajo 5346, No 1 , folios 91-102; folios 134-143; folios 209-215; folios 168-175; folios 101-109; legajo 5346, № 2, folios 110-116; folios 35-47). También existían conjuros en que las hechiceras utilizaban animales considerados repugnantes y diabólicos, entre los más comunes eran las serpientes y los sapos. Francisca de Mondragón era una de las que manipulaba sapos en sus conjuros, pues creía que dicho animal le mostraba la totalidad de mal que podía hacer en los demás (folios 45-46).

Nos llama la atención un hecho singular: no siempre, por no decir nunca, los hechizos producían los resultados esperados. Las clientas, entonces, perdían tiempo y, sobre todo, dinero en intentar conseguir un objetivo inalcanzable. Era muy habitual entre los inquisidores cuestionar si dichos conjuros habían sido efectivos. La respuesta a estos cuestionamientos, salvo algunas excepciones, era siempre negativa. De ahí que acudir a la hechicería era una forma de consuelo para las personas angustiadas. En relación a la inutilidad de los hechizos, recordamos el proceso contra Paula Molina celebrado en Lima con fecha septiembre de 1778: una de las testigos declaró que "abria un año que Ygnacia Mantilla hablo a esta reo para que Juan de Mundaca con quien trataba la quisiese, a que la llebo a mula auna pampilla y bajándose arranco las primeras yerbas que encontró y con ella le refregó bajo de ambos brazos diciéndola que con aquello lograría su deseo que no se verifico" (AHN Inquisición). Rosa Crespo, también testigo de Paula Molina, expresó algo parecido, pues en la segunda audiencia declaró que

a fin de que un hombre español nombrado Manuel de exercicio herrero con quien había tratado ilícitamente volviese asu amistad y ofreciendola dos pesos por luenar estos la hizo comprar una mitad de pimiento seco y otra de melao, y la unto todo el cuerpo persuadiendola a que de aquel modo conseguiría satisfacer su deseo, no siendo mas que un puro engaño (AHN Inquisición).

Por otro lado, las hechiceras eran mujeres cuyas vidas se asemejaban mucho a las de sus clientas, es decir, también eran mujeres desdichadas e inseguras socialmente; algunas veces, se les acusó de mantener una vida moral lejos de lo establecido y se las catalogó de celestinas o alcahuetas e incluso de prostitutas, por lo tanto, "las hechiceras se hallaban con frecuencia 
cargadas de injurias que hacían referencia a los comportamientos sexuales de las mismas" (Tausiet, 2004: 536). Estas denuncias, provenían de las mismas clientas e incluso de otras sortílegas, pues

la realidad cotidiana, guiada por intereses oscuros, volvía a imponerse sobre ese mundo imaginario, optimista y abierto a infinitas posibilidades que representaba la magia para una buena parte de la población. Por ello, su práctica acabó casi siempre tornándose un recurso efímero que, en lugar de abrir puertas, confinó a sus seguidores en un entramado de acusaciones, envidias y recelos del que resultaba muy difícil escapar (Tausiet, 2004: 538).

De ahí que la siguiente afirmación, de Sánchez Ortega, tuviese un sustrato veraz: "la magia amorosa es también una magia extra-conyugal" (2004: 441). Ya dijimos que algunas mujeres buscaban casarse sólo para tener más libertad amorosa. De ahí que muchas veces el vínculo eróticosentimental lo sustentaban en relaciones de pareja no reconocidas legalmente. En tal caso, observa Sánchez Ortega: "Las expertas y sus clientas buscan el trato ilícito, procuran actos torpes, usan fluidos que proceden de las partes vergonzosas, están interesadas en las relaciones deshonestas..." (2004: 441). Asimismo, la magia amorosa "puede ser interpretada... como un proceso a través del cual se observan las distintas etapas del amor, y las diversas circunstancias por las que atraviesa psicológicamente la mujer -o el hombre- en sus relaciones erótico-sentimentales" (2004: 423). Es decir, en algunos conjuros sólo buscaban al amor deseado, en otros intentaban retenerlo o reconquistarlo. Y no olvidemos aquellos conjuros que servían para deshacerse o ahuyentar al otro. Por consiguiente, los hechizos amorosos nos transmiten un ramillete de emociones y pensamientos. Emociones y pensamientos que también se relacionan con cuestiones sociales, culturales, complejas y con la brujería y la magia. Esas cuestiones son la invocación de las culturas originarias, en el caso de los negros; el escape del rígido mundo colonial, en el caso de las mujeres hispanas y criollas blancas; el abrir un espacio de resistencia al poder invasor por medio del rescate de la lengua y la cultura, en el caso de las indias. Pero estos asuntos, mirándolos bien, son también formas de amor. Amor por el África extirpada, en el caso de las negras; por la vida plena, en el caso de hispanas y criollas; por la tierra y la cultura silenciada, en el caso de las indias.

Consideración final: dijimos arriba que la complejidad del asunto hechiceril se termina por relacionar también con la brujería y con la magia. Ello en razón que existe una distinción entre esas prácticas. La hechicería es 
un intento por lograr un fin mediante conjuros. La brujería, por su parte, tiene que ver con el chamanismo. La bruja está profundamente vinculada a la tierra, estudia los poderes curativos de plantas, sabe detener hemorragias, conoce los mecanismos de la naturaleza y los principios de la humedad y la sequía. La magia, por último, funciona como una actividad mental. La magia confía en los poderes del lenguaje y del pensamiento. La alquimia, por ejemplo, es un trabajo hacia el interior del mago, el quiere transformar su ser en un ser áureo, noble. Claramente la magia es una cuestión elitista. Frente a esa constatación, evidentemente la hechicería pertenece a la cultura popular, es más inocente, pues recoge principios de la magia y cree poder hacerlos operativos mediante el conjuro. Para lograr este objetivo, recordemos que las hechiceras coloniales recurrían a la fuerza de la palabra. Aquí se marca, precisamente, el vínculo con las complejidades de la magia. A pesar de su insuficiente cultura, de su vida marginal, de su imposibilidad de vincularse con los antiguos, la hechicera limeña comprende que hay algo más, allá en el afuera, e intenta, por todos los medios vincularse con ello. Nunca lo hará, pero en su travesía logró superar la rígida estratificación social, sacudirse del alma que les había impuesto la colonia, dar esperanzas a los solitarios y abrirse hacia la máxima alteridad. Apertura marcada en los sincréticos hechizos que hemos conocido de la Lima virreinal.

\section{REFERENCIAS}

Archivo Histórico Nacional de Madrid, Sección Inquisición, Procesos de Fe del Tribunal de Lima, Legajo 1649.

Archivo Histórico Nacional de Madrid, Sección Inquisición, Procesos de Fe del Tribunal de Lima, Legajo 1656.

Archivo Histórico Nacional de Madrid, Sección Inquisición, Relaciones de Causa del Tribunal de Lima, Legajo 5345.

Archivo Histórico Nacional de Madrid, Sección Inquisición, Relaciones de Causa del Tribunal de Lima, Legajo 5346.

Caro Baroja, J. (1967). Vidas mágicas e inquisición (Vols. II y III). Madrid: Taurus.

Castañeda, P. y Hernández, P. (1995). “Los delitos de superstición en la Inquisición de Lima del siglo XVII". Revista de la Inquisición 4, 9-35.

Ceballos, D. (2001). "Grupos mágicos y prácticas mágicas en el Nuevo Reino de Granada durante el siglo. XVII”. Historia Crítica 22, 51-71.

Deleuze, G. (2000). Mil mesetas. Barcelona: Pretextos.

Díaz, R. (2005). "Entre demonios africanizados, cabildos y estéticas corpóreas: Aproximaciones a las culturas negra y mulata en el Nuevo Reino de Granada". Universitas Humanística Vol. XXXII, No 60, julio-diciembre, 29-37. 
Foucault, M. (2000). El pensamiento del afuera. Barcelona: Pretextos.

Mannarelli, M. E. (1998). Hechiceras, beatas y expósitas. Mujeres y poder inquisitorial en Lima. Lima: Ediciones del Congreso del Perú.

Maya, L. A. (2002). "Apuntes para el Estudio del Cimarronaje Femenino en el Caribe, Siglo XVII". Historia Crítica 24, 101-124.

Millar, R. (1998). Inquisición y sociedad en el virreinato peruano. Santiago: Ediciones Universidad Católica de Chile.

Millones, L. y León, L. (2003). "Hechizos de amor: Poder y magia en el norte del Perú”. Tradición popular Senri Ethnological Reports 43, 149-177.

Ramos, G. (1994). "La venida del reino. Religión, evangelización y cultura en América (siglos XVI-XX)”. Cuadernos para la historia de la evangelización en América Latina. Cusco: Centro de Estudios Regionales Andinos Bartolomé de Las Casas.

Sánchez, A. (1997). "El talismán del Diablo. La Inquisición frente al consumo de coca. (Lima, siglo XVII)". Revista de la Inquisición 6, 139-162.

Sánchez Ortega, M. H. (2004). Ese viejo Diablo llamado amor. La magia amorosa en la España moderna. Madrid: Ediciones UNED.

Tausiet, M. (2004). Ponzoña en los ojos. Hechicería y superstición en Aragón en el siglo XVI. Madrid: Turner Publicaciones. 